\title{
DEMOGRAPHICS INFLUENCE ON FACULTY PERCEPTION TOWARDS WORK ENVIRONMENT: A STUDY OF KERALA BUSINESS SCHOOLS
}

\author{
*Asha Sara Mammen
}

**Dr. Harold Andrew Patrick

\begin{abstract}
Demographic attributes of an employee results in significant difference in attitudes and beliefs which leads to difference in perception. This paper investigates the difference in viewpoint in faculty members based on their characteristics such as gender, marital status, educational qualification and designation towards the nine dimensions of work environment. Survey data was collected from a sample of 182 faculty members working in AICTE recognized and state university affiliated business schools in Kerala by administering standardized, valid and reliable tools. Independent sample t-test and one-way ANOVA were used to analyse data. Findings show that there was significant difference in perception towards the various dimensions of work environment across marital status, educational qualification and designation. There was no significant difference in perception across gender. The implications, findings and suggestions for future research are detailed.
\end{abstract}

Keywords: Work Environment, Demographics, Organisational Behaviour, Human Resource Management, Business Schools, Management Education, Faculty, Kerala.

\section{INTRODUCTION}

Human Resource Management and Organisational Behaviour disciplines speak of practices and policies that are applied mostly to the entire human resource of an organisation. The assumption made regarding the human resource is that it is homogeneous in nature and employee's viewpoint towards these practices and policies are mostly similar (Wood, 1995; Purcell, 1999). Previous research studies have commonly analysed the perception of employees towards the various study constructs taking into consideration the viewpoint or response of either the higher level officers or human resource managers. This may not match the exact response of the other employees and hence it can be said that they are not considered for research study. To get better measures, findings and understanding of the construct under study, the direct response from the employees themselves need to be taken by using the demographics of the respondents (Edgar \& Geare, 2004). This paper focuses on the difference in perception towards work environment dimensions by considering the

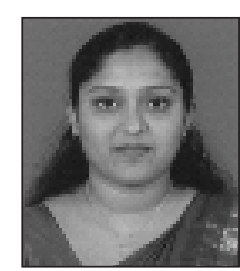

*Prof. Asha Sara Mammen

Assistant Professor,

T.John Institute of Management \& Science, Bengaluru

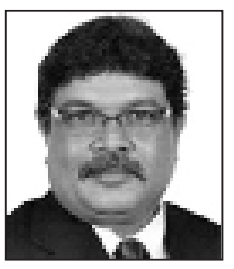

*Dr. Harold Andrew Patrick Professor - OB and HRM Area, Institute of Management, Christ University, Bengaluru 
different demographic variables of business school faculty members. This will enable organisational authorities to make decisions and appropriately cater to the psychological needs of its employees leading to more organisational loyalty.

\section{DEMOGRAPHICS}

According to Pfeffer (1983), employee demographics is the study of the composition of a social entity based on attributes of its individual members that it is made up of. Demographic variables include age, gender, marital status, tenure of work experience, name of the department, ethnicity etc. Respondents' profiles or demographics play a critical role in research study in the field of human resource management and organisational behaviour. As quoted in the research study by Edgar \& Geare (2004), ignoring the aspects of employee demographic is creating a black box where contribution to the body of knowledge by research work is reduced or interrupted.

Workforce in any organisation exhibit differences with respect to demographic variables. Research study by Shenhav \& Haberfeld (1992) show that there is an increase in the number of women in the workforce as well as an increased number of different ethnic groups. These demographic variables influence the manner of thinking, outlook and response to occurrences that take place in the work environment. If employees' opinions and feedbacks are considered in a research process, it would be appropriate to also measure their demographics. Research work by Konrad \& Hartman (2002) report that a difference in attitude and behaviour is associated with difference in gender. Gibbs (2001) study findings show that demographic differences are linked with difference towards perception of human resource management practices. Konrad \& Hartman (2002) research findings show that demographic differences are linked to varied perception towards equal employment opportunity scheme with women and ethnic group members highly perceiving than men.

\section{WORK ENVIRONMENT}

A healthy work environment is operationally defined as one where there is a level of employee trust towards the management, where employees have pride in what they do and enjoy working with their colleagues (Levering \& Moskawitz, 2004). Kahn (1990) argue that employees engage themselves and invest more time and effort in the organisation's work, if they have a higher perception that the work environment satisfies their psychological needs resulting in greater organisational performance, productivity and competitiveness. Turnipseed \& Murkison (2000) study indicated that organisational citizenship behaviour was linked to higher perception of work environment dimensions such as commitment, peer relations, autonomy, the physical work environment, task clarity, supervisor support, work stress, and the amount of bureaucracy in the organization. Seister (1984) study on the work environment of full time faculty in community colleges reported low on cohesion, clarity and innovation. Findings also show a link facilitation leadership and work milieu that is predictable and clear leading to educational efficiency. Higher faculty commitment was positively linked to peer 
cohesion and task orientation and negatively linked to high work demand and control. Capell (1981) study on school teachers found a link between faculty cohesion and autonomy exercised by faculty in classrooms on positive performance of students. Brody, Kinnaird, \& Friedrich (1980) study showed that those employees whose work environment had higher level of autonomy, support, involvement, cohesion and involvement showed more job satisfaction. Higher work demand led to emotional exhaustion. Turnipseed (1994) research finding show that lesser perception of work environment variables such as peer cohesion, stress and work pressure, superior support, job, role clarity and autonomy were linked to burnout.

\section{Need and Rational of the study}

Teaching is a noble profession. Sincere roles played by faculty have long term advantages ultimately resulting in a nation's progress. Education has the possibility to harness India's great demographic dividend (Jaipuria, 2014). Tsai (2012) describes faculty members as forerunners of academic quality and excellence. They exercise responsibilities; take, make and implement decisions and are subject to decisions made by higher levels of hierarchy which have socio-emotional and economic consequences influencing faculty attitude and behaviour. These faculty members are influenced by the various aspects of their workplace. This papers' focus is on the qualitative aspects of work environment and how faculty members perceive them. Quantitative aspects of the workplace like infrastructure and facilities depends mostly on the financial capacity of an institution but lasting and effective influence takes place through the qualitative aspects of the work environment. Faculty perception towards nine qualitative and psychological dimensions are considered for this study such as ethical dimensions, autonomy, stress and work pressure, work practices, managerial support, commitment, role clarity, social responsibility and peer cohesiveness. This paper aims to contribute scientifically to the body of knowledge by which appropriate measures and interventions can be designed to enhance positive faculty contributions.

\section{Research Question}

Does difference in the demographic characteristics of faculty member lead to difference in how work environment dimensions are perceived $\mathrm{fl}$

\section{Objective of the study}

- To find out whether difference in perception towards work environment dimensions exists across demographics (gender, marital status, education qualification, designation).

\section{METHODOLOGY}

\section{Statistical Population and Sample}

The elements of the population included in the study are private unaided self-financing business school faculty in Kerala. Business schools which are recognised by All India Council for Technical Education (AICTE) and affiliated to the universities in the state of Kerala are considered. There 61 business schools with a faculty population size of 366 . Based on the 
model by Krejcie \& Morgan (1970), the sample size calculated was 182 . The researcher used multi-stage sampling to select sample which included cluster sampling and simple random sampling such that there was sufficient representation of the population. Cluster sampling was used by dividing the state of Kerala into 14 districts which are broadly classified into three regions: North Kerala, Central Kerala and South Kerala. Simple random sampling was used to select colleges from each district and also faculty from each college. The response rate was $86.67 \%$.

\section{MEASUREMENT TOOLS}

Work Environment Services Scale (WESS)*, Patrick, H.A. (2013) was used to measure work environment which consists of nine dimensions and 32 items. The nine dimensions are ethical dimensions (4 items), autonomy (4 items), stress and work pressure (5 items), work practices (2 items), managerial support (3 items), commitment (2 items), role clarity (4 items), social responsibility (2 items) and peer cohesiveness ( 2 items). Items were measured on a 5-point Likert scale from Never-1 to Always5. Ten reverse coded items were scored from Always-1 to Never-5. The Cronbach's alpha obtained was 0.86 .

*Work Environment Services Scale (WESS)* was developed as part of Major Research Project (MRP) funded by Christ University, Bangalore.

There were nine demographic variables considered for the study which include gender, marital status, educational qualification and designation.

\section{RESPONDENTS PROFILE}

Respondents profile was obtained from the demographic variables. Among the faculty, $42.3 \%$ were male and $57.7 \%$ were female. Respondents in the age group below 35 years constituted $62 \%$ and above 36 years were $38 \%$. Marital status showed $22.5 \%$ to be single, $75.8 \%$ married and $1.6 \%$ of others. Of the participants, $54.9 \%$ had an MBA degree, 23.1\% MPhil, $12.6 \% \mathrm{PhD}$ and $9.3 \%$ included other educational qualification. The designation of the respondents included 3.3\% of Lecturers, $77.5 \%$ of Assistant Professsor, 10.4\% Associate Professors and $8.8 \%$ of Professors. Tenure with current organisation showed $48.4 \%$ for $0-2$ years followed by $30.2 \%$ for $2-4$ years, $9.9 \%$ for $4-6$ years, $7.7 \%$ for $6-10$ years, $2.7 \%$ between $10-15$ years and $1.1 \%$ between $15-20$ years. The tenure of teaching experience was $23.6 \%$ for $2-4$ years, $22.5 \%$ for $6-10$ years, $14.3 \%$ for $4-6$ years, $13.7 \%$ for $10-15$ years, $11 \%$ for above 20 years and $4.9 \%$ for $15-20$ years. The highest percentage of industrial experience of $22.5 \%$ was between 6-10 years and lowest of $4.9 \%$ was between $15-20$ years. $23.1 \%$ of faculty had tenure of work experience between 10-15 years followed by $18.7 \%$ for $4-6$ years, $17.6 \%$ between 6-10 years, $15.4 \%$ each for $15-20$ years and above 20 years and $9.9 \%$ between 2-4 years.

\section{RESULTS AND DISCUSSION}

Hypothesis 1 - There will be no difference in work environment dimensions across demographics. 
Hypothesis 1a - There will be no difference in work environment dimensions across gender.

Table 1 indicating Group Statistics \& Independent Sample t-test

Group Statistics \& Independent Sample t-test

\begin{tabular}{|c|c|c|c|c|c|c|c|c|c|c|c|c|c|c|c|c|c|}
\hline \multirow{2}{*}{$\begin{array}{c}\text { Work Environment } \\
\text { Dimension } \\
\text { Gender }\end{array}$} & $\begin{array}{c}\text { Ethical } \\
\text { Dimension }\end{array}$ & \multicolumn{2}{|c|}{ Autonomy } & \multicolumn{2}{|c|}{$\begin{array}{c}\text { Stress \& } \\
\text { Work } \\
\text { Practices }\end{array}$} & \multicolumn{2}{|c|}{$\begin{array}{c}\text { Work } \\
\text { Practices }\end{array}$} & \multicolumn{2}{|c|}{ Commitment } & \multicolumn{2}{|c|}{ Role Clarity } & \multicolumn{2}{|c|}{$\begin{array}{c}\text { Social } \\
\text { Responsiveness }\end{array}$} & \multicolumn{2}{|c|}{$\begin{array}{c}\text { Managerial } \\
\text { Support }\end{array}$} & \multicolumn{2}{|c|}{$\begin{array}{c}\text { Peer } \\
\text { Cohesion }\end{array}$} \\
\hline & Male Female & Male & Female & Male 1 & Female & Male & Female & Male & Female & Male & Female & Male & Female & Male & Female & Male & Female \\
\hline Mean & \begin{tabular}{|l|l|}
3.31 & 3.33 \\
\end{tabular} & 3.34 & \begin{tabular}{|l|}
3.18 \\
\end{tabular} & 3.36 & 3.14 & 3.45 & 3.42 & 3.62 & 3.77 & 2.92 & 3.43 & 3.05 & 3.21 & 3.39 & 3.24 & 3.58 & \begin{tabular}{|l|}
3.66 \\
\end{tabular} \\
\hline SD & \begin{tabular}{|l|l}
0.86 & 0.87 \\
\end{tabular} & 0.73 & 0.7 & 0.76 & \begin{tabular}{|l|}
0.71 \\
\end{tabular} & 0.86 & 0.92 & 0.71 & 0.73 & 1.12 & 0.92 & 1.06 & 0.9 & 0.8 & 0.84 & 0.72 & 0.8 \\
\hline $\begin{array}{c}\mathrm{F} \\
\text { (Equal variance assumed) }\end{array}$ & -0.13 & \multicolumn{2}{|c|}{1.44} & \multicolumn{2}{|c|}{2.04} & \multicolumn{2}{|c|}{0.18} & \multicolumn{2}{|c|}{-132} & \multicolumn{2}{|c|}{-3.35} & \multicolumn{2}{|c|}{-1.16} & \multicolumn{2}{|c|}{1.25} & \multicolumn{2}{|c|}{-0.73} \\
\hline $\begin{array}{c}\mathrm{F} \\
\text { (Equal variance not assumed) }\end{array}$ & -0.13 & \multicolumn{2}{|c|}{1.44} & \multicolumn{2}{|c|}{2.02} & \multicolumn{2}{|c|}{0.18} & \multicolumn{2}{|c|}{-132} & \multicolumn{2}{|c|}{-3.25} & \multicolumn{2}{|c|}{-1.13} & \multicolumn{2}{|c|}{1.26} & \multicolumn{2}{|c|}{-0.74} \\
\hline Sig. & 0.74 & \multicolumn{2}{|c|}{0.33} & \multicolumn{2}{|c|}{0.61} & \multicolumn{2}{|c|}{0.22} & \multicolumn{2}{|c|}{0.98} & \multicolumn{2}{|c|}{0.06} & \multicolumn{2}{|c|}{0.15} & \multicolumn{2}{|c|}{0.62} & & 0.19 \\
\hline $\mathrm{t}$ & -0.13 & & .44 & & 2.04 & & .18 & & 132 & & 3.35 & & -1.16 & & 1.25 & & 0.73 \\
\hline
\end{tabular}

Source: SPSS output generated from primary data

Note : $\mathrm{df}=180$, Sig. at 0.05

From the table 1, group statistics show that some work environment dimensions such as autonomy, stress and work pressure, work practices, managerial support were perceived higher by male faculty members in comparison with female faculty members. The other work environment dimensions such as ethical dimensions, commitment, role clarity, social responsiveness, peer cohesion were perceived higher by female faculty member. But the output of independent sample t-test show that the above gender based perception not to be statistically significant at 0.05 . Both male and female faculty member have almost similar perception towards the nine dimensions of work environment. Thus null hypothesis is accepted: There is no significant difference in perception of work environment dimensions across gender.

Hypothesis 1b-There will be no difference in work environment dimensions across marital status

Table 2 indicating ANOVA for work environment dimensions across marital status

\begin{tabular}{|c|c|c|c|c|c|c|c|c|c|}
\hline $\begin{array}{c}\text { Work Environment } \\
\text { Dimension }\end{array}$ & $\begin{array}{c}\text { Ethical } \\
\text { Dimension }\end{array}$ & Autonomy & $\begin{array}{c}\text { Stress \& } \\
\text { Work }\end{array}$ & $\begin{array}{c}\text { Work } \\
\text { Practices }\end{array}$ & Commitment & $\begin{array}{c}\text { Role } \\
\text { Clarity }\end{array}$ & $\begin{array}{c}\text { Social } \\
\text { Responsiveness }\end{array}$ & $\begin{array}{c}\text { Managerial } \\
\text { Support }\end{array}$ & $\begin{array}{c}\text { Peer } \\
\text { Cohesion }\end{array}$ \\
\hline F & 0.99 & 6.04 & 0.52 & 0.37 & 6.46 & 1.16 & 4.2 & 0.2 & 1.08 \\
\hline Sig. & 0.37 & 0 & 0.59 & 0.69 & 0 & 0.32 & 0.02 & 0.82 & 0.34 \\
\hline
\end{tabular}

Source: SPSS output generated from primary data

Note : $\mathrm{df}=180$, Sig. at 0.05

From table 2, it is seen that there was significant

Autonomy (3.3496) and was perceived highest difference in work environment dimensions namely autonomy, commitment and social responsiveness across marital status at 0.05 level by married respondents which is in line with Kerala's culture and tradition where respect and value to are given more to people with a normal of significance. Commitment (3.8116) and married status. The management accepts such 
people to be better psychologically advanced in their rational thinking leading to the assumption of sticking with the organisation along with more autonomy. Social responsiveness (3.5) was highly perceived by respondents who to the category-others, who live and work in a culture that are critical to their status. They are still able to work in such an environment making them respond with higher perception towards social responsiveness. The null hypothesis is failed to be accepted for work environment dimensions such as commitment, autonomy and social responsiveness across marital status and its alternative hypothesis is accepted. There is a significant relationship between certain work environment dimensions across marital status

\section{Hypothesis 1c - There will be no difference in work environment dimensions across levels of educational qualification}

Table 3 indicating ANOVA for work environment dimensions across levels of educational qualification

ANOVA

\begin{tabular}{|c|c|c|c|c|c|c|c|c|c|}
\hline $\begin{array}{c}\text { Work Environment } \\
\text { Dimension }\end{array}$ & $\begin{array}{c}\text { Ethical } \\
\text { Dimension }\end{array}$ & Autonomy & $\begin{array}{c}\text { Stress \& } \\
\text { Work }\end{array}$ & $\begin{array}{c}\text { Work } \\
\text { Practices }\end{array}$ & Commitment & $\begin{array}{c}\text { Role } \\
\text { Clarity }\end{array}$ & $\begin{array}{c}\text { Social } \\
\text { Responsiveness }\end{array}$ & $\begin{array}{c}\text { Managerial } \\
\text { Support }\end{array}$ & $\begin{array}{c}\text { Peer } \\
\text { Cohesion }\end{array}$ \\
\hline F & 1.24 & 0.24 & 0.96 & 0.88 & 2.58 & 3.11 & 0.23 & 1.49 & 1.45 \\
\hline Sig. & 0.3 & 0.87 & 0.41 & 0.45 & 0.05 & 0.03 & 0.88 & 0.22 & 0.23 \\
\hline
\end{tabular}

Source: SPSS output generated from primary data

Note : $\mathrm{df}=180$, Sig. at 0.05

From table 3, it was found that there was significant difference in work environment dimension namely role clarity across different academic qualification at sig. 0.05. Role Clarity (3.4881) was perceived highest by respondents with research oriented qualifications. Other dimensions showed no significant difference. The null hypothesis is failed to be accepted for the work environment dimension such as role clarity across educational qualification and its alternative hypothesis is accepted. There is a significant relationship between role clarity across educational qualification.

\section{Hypothesis 1d - There will be no difference in work environment dimensions across designations}

Table 4 indicating ANOVA for work environment dimensions across designations

\begin{tabular}{|c|c|c|c|c|c|c|c|c|c|}
\hline $\begin{array}{c}\text { Work Environment } \\
\text { Dimension }\end{array}$ & $\begin{array}{c}\text { Ethical } \\
\text { Dimension }\end{array}$ & Autonomy & $\begin{array}{c}\text { Stress \& } \\
\text { Work }\end{array}$ & $\begin{array}{c}\text { Work } \\
\text { Practices }\end{array}$ & Commitment & $\begin{array}{c}\text { Role } \\
\text { Clarity }\end{array}$ & $\begin{array}{c}\text { Social } \\
\text { Responsiveness }\end{array}$ & $\begin{array}{c}\text { Managerial } \\
\text { Support }\end{array}$ & $\begin{array}{c}\text { Peer } \\
\text { Cohesion }\end{array}$ \\
\hline F & 0.14 & 0.92 & 0.57 & 1.6 & 0.78 & 4.14 & 2.44 & 0.04 & 0.28 \\
\hline Sig. & 0.93 & 0.43 & 0.63 & 0.19 & 0.51 & 0.01 & 0.07 & 0.99 & 0.84 \\
\hline
\end{tabular}

Source: SPSS output generated from primary data

Note $: \mathrm{df}=180$, Sig. at 0.05

It was found, from table 4 that there was significant difference in work environment dimension namely role clarity across the different designations at sig. 0.05. Role Clarity (4.00) was perceived highest by Lecturers. Other dimensions showed no significant difference among designations. The null hypothesis is failed to be accepted for work environment dimensions such as role clarity across designation-Lecturers and its alternative hypothesis is accepted. There is a significant relationship between certain work environment dimensions across designation. 


\section{Suggestions}

The demographics of the faculty members such as marital status, educational qualification, designation contributed to significant difference in perception towards work environment dimensions. Four dimensions out of the nine work environment dimensions were perceived differently by faulty members. The four dimensions are autonomy, commitment, role clarity and social responsiveness. The current study suggests academic authority to design and implement measures that can improve autonomy, commitment, role clarity and social responsiveness dimensions for academic faculty members.

Research and real situational scenarios show that an optimal amount of autonomy increases job satisfaction and performance. Measures such as giving parameters to employees and then allowing employees to make choices encourages them to take up responsibilities that they want to do. They treat their job task as an opportunity to make a great impression and to work more devotedly to give an output. Along with instilling strong belief in the institution's value system and obtaining feedback from the customers have contributed to higher benefits from optimal level of autonomy (Prevost, 2014). This can be implemented also in teaching organisations.

Research show that higher the commitment, higher the level of motivation and engagement. Certain philosophical and psychological steps taken to increase commitment in real life scenarios use human connections by making time by to communicate with each other at the workplace, giving praise and commendation from reporting authority and connecting one's work with meaning and value however small it is (Debow, 2011). These steps have contributed to more engaged employees and hence can be implemented in educational institutions.

Some of the best faculty are those that are responsive to the difficulties and limitations of students. Organisations that show responsiveness to its employees are also teaching their employees to be responsive to their clients or customers. This way of thinking can be applied to the value system of a teaching institution also. Role clarity play a critical role since it leads to accountability which leads to actions, without actions there can't be measurements to know how one is doing. Some of the steps taken by successful companies to improve role clarity are by having organisational chart, job description, proper channel of communication and standard operating procedures. Employees can be involved in the process of creating and communication these practices (Uglow, 2013) which will also work in an educational institution.

\section{Limitations and Scope for further study}

The present study has considered only four aspects of demographics and qualitative aspects of work environment dimensions. Further study can be done by taking into consideration other dimensions of the construct. The study is done only on private colleges that offer management education.

\section{CONCLUSION}

Attitudes and beliefs change with difference in demographics which is supported by the research findings of Edgar \& Geare (2004) and Pratistha \& Gupta (2014). Demographic variables can predict the behaviour of employees (Pfeffer, 1985; Stewman, 1988) which will help policy makers and practitioners 
in developing initiatives to control counterproductive behaviour and increase positive and healthy responses. Group members that differ from each other in various demographic characteristics had linkage with increased employee turnover (Jackson, Brett, Sessa, Cooper, Julin \& Peyronnin, 1991). Literature review show that better perception of work environment contribute to the well-being of the employees and organisation. Management and superiors can do their best to achieve those aspects which leads to a virtuous cycle where employees can contribute towards the positive work outcomes and reduce negative work outcomes. This creates a sense of belonging to the organisation with loyal employees which is a competitive advantage that ensures success in a competitive environment.

\section{REFERENCES :}

- $\quad$ Brody, C., Kinnaird, K., \& Friedrich, W. (1980). Job satisfaction and perception of social climate in a mental health facility.Perpectual and motor skills, 51, $559 \& 564$.

- $\quad$ Capell, F. (1981). A study of alternatives in American education: Student outcomes at Alum Rack 1974-76. Santa Monica, CA: Rand Corporation.

- Debow, D. (2011, Mar 3).Three ways to boost commitment at work. Retrieved from http:// fortune.com / $2011 / 03$ / 03 / three-ways-to-boost-commitment-at-work/

- $\quad$ Edgar, F., \& Geare, A. (2004). Employee Demographics in Human Resource Management Research, Research and Practice in Human Resource Management, 12(1), 61-91.

- Gibb, S. (2001). The state of human resource management: Evidence from employees' views of HRM systems and staff. Employee Relations. 23(4), 318-336.

Jackson,S.E., Brett,J.F., Sessa,V.I., Cooper,D.M., Julin,J.A., \& \& Peyronnin,K.(1991).Some differences make a difference: Individual dissimilarity and group heterogeneity as correlates of recruitment, promotions and Turnover. Journal of Applied Psychology, 76 ( 5 ) , 675-689.

Jaipuria, S. (2014, July 21). Higher education in India: introspection. The Times of India. $\mathrm{R}$ e $\mathrm{t} \mathrm{r}$ e $\mathrm{i} \mathrm{v}$ e d $\mathrm{f} \mathrm{r}$ o $\mathrm{m}$ http://timesofindia.indiatimes.com/home/e ducation/news/Higher-India-A n introspection/articleshow/38776482.cms

Kahn, W. A. (1990). Psychological conditions of personal engagement and disengagement at work. Academy of management journal, 33(4), 692-724.

Konrad, A. M., \& Hartmann, L. (2002). Gender differences in attitudes toward affirmative action programs in Australia: Effects of beliefs, interests, and attitudes towards women. Gender Roles, 4 5( 5 - 6 ), 415-432.

- $\quad$ Krejcie, R. V., \& Morgan, D. E. (1970). Determining sample size for research activities. Educational and Psychological Measurements.

Levering, R., \& Moskowitz, M. (2004).Creating a great place to work: Why it is important and how it is done. Corrections Today, 66(5), 86-88.

Mammen, A. S. (2014). Work environment influence on turnover intentions: The moderating role of organisational justice among business school faculty in Kerala. Unpublished MPhil Thesis, Christ University Institute of Management, Bangalore, India. 
- $\quad$ Margaret, D. S. (2009). College teachers' perception of organizational justice and its influence on organizational commitment. Unpublished MPhil Thesis, Christ University Institute of $\mathrm{M}$ a $\mathrm{n}$ a $\mathrm{g}$ e $\mathrm{m}$ e $\mathrm{n} \mathrm{t}$, Bangalore, India.

- $\quad$ Matin, H. Z., Kalali, N. S., \& Anvari, M. R. A. (2012). Do demographic variables moderate the relationship between job burnout and its consequencesfl. Iranian Journal of Management Studies, 5(1), 4762.

- P., \& Gupta, P. (2014). Impact of demographics dynamics on distributors' perception regarding products offered through network marketing companies. Presidency Journal of Management Thought \& Research, 4(2), 27-36.

- Patrick, H.A. (2012). Commitment of information technology employees in relation to perceived or $\mathrm{g}$ a $\mathrm{n}$ i s a $\mathrm{t}$ i o $\mathrm{n}$ a $\mathrm{l}$ justice. The IUP Journal of Organisational Behaviour, 11(4), 23-40.

- Patrick, H.A. (2013). Manuel of Work Environment Services Scale, Christ University.

- Patrick, H.A., Mammen, A. S., \& Margaret, D. S. (2014). Organisational justice in higher educational institutions. (Unpublished research paper).

- Pfeffer, J. (1983). Organizational demography. In L. L. Cummings \& B. M Staw (Ed.), Research in organizational behavior (Vol 2, 299-357). Greenwich, C.T: JAI Press.

- $\quad$ Prevost, S. (2014, Mar 31).The compelling case for giving employees more freedom. Retrieved http://www.inc.com/shelley-prevost/5ways-to-create-more-autonomy-atwork.html

Purcell, J. (1999). Best practice and best fit: Chimera or cul-de-sacfl Human Resource Management Journal, 9(3), 2641.

Seiter, S. (1984). The relationship between leader behavior and the work environment. Dissertation Abstracts International, 45,1661A

Shenhav, Y., \& Haberfeld, Y. (1992). Organizational demography and inequality. Social Forces, 71(1), 123-143.

Tsai, M. C. H. (2012). An empirical study of the conceptualization of overall organizational justice and its relationship with psychological empowerment, organizational commitment and turnover intention in higher education. (Doctoral dissertation, University of Washington).

Turnipseed, D. L. (1994), An Analysis of the influence of work environment variables and moderators on the burnout syndrome. Journal of Applied Social Psychology, 24: 782-800. doi: 10.1111/j.1559-1816.1994.tb00612.x

Turnipseed, D., \& Murkison, G. (2000). Good soldiers and their syndrome: Organizational citizenship behavior and the work environment. North American Journal of Psychology.

Ugloy, P. (2013, Nov 18). Role clarity s e c r e t s. Retrie ved from http://www.renshicon.com/blog/bid/29634 3/Role-Clarity-Secrets

Wood, S. (1995). The four pillars of HRM: Are they connectedfl Human Resource Management Journal, 5(5), 49-60. 